\title{
Diversity Jurisdiction Over Alien Corporations
}

\section{Diversity jurisdiction has long been controversial. ${ }^{1}$ Argu-}

ments have been made for its elimination, ${ }^{2}$ alteration, ${ }^{3}$ retention, ${ }^{4}$

I See, e.g., P. Bator, P. Mishkin, D. Shapiro \& H. Wechsler, Hart \& Wechsler's Federal Courts and the Federal System 1053-59 (2d ed. 1973); Frank, Historical Bases of the Federal Judicial System, 13 Law \& Contemp. Props. 3 (1948); Moore \& Weckstein, Diversity Jurisdiction: Past, Present, and Future, 43 TEx. L. Rev. 1 (1964); Phillips \& Christenson, The Historical and Legal Background of the Diversity Jurisdiction, 46 A.B.A. J. 959 (1960).

2 The leading advocate for elimination of diversity jurisdiction was Justice Frankfurter. See Lumbermen's Mut. Casualty Co. v. Elbert, 348 U.S. 48, 53-60 (1954) (Frankfurter, J., concurring); National Mut. Ins. Co. v. Tidewater Transfer Co., 337 U.S. 582, 650-51 (1949) (Frankfurter, J., dissenting); Frankfurter, Distribution of Judicial Power Between United States and State Courts, 13 CoRnell L.Q. 499, 520-26 (1928). This position has been advocated by other judges, e.g., Bork, Dealing with the Overload in Article III Courts, 70 F.R.D. 231, 236-37 (1976); Burger, Annual Report on the State of the Judiciary, 62 A.B.A. J. 443, 444 (1976), as well as by scholars, e.g., Federal Diversity of Citizenship Jurisdiction: Hearings on S. 2094, S. 2389 \& H.R. 9622 Before the Subcomm. on Improvements in Judicial Machinery of the Senate Comm. on the Judiciary, 95th Cong., 2d Sess. 44-63 (1978) (statement and testimony of Prof. Charles A. Wright) [hereinafter cited as 1978 Hearings]; Clark, Diversity of Citizenship Jurisdiction of the Federal Courts, 19 A.B.A. J. 499 (1933); Currie, The Federal Courts and the American Law Institute (pts. 1 \& 2), 36 U. CHI. L. REv. 1, 268 (1968); Kurland, The Distribution of Judicial Power Between National and State Courts, 42 J. Am. Judicature Soc'y 159 (1959); Rowe, Abolishing Diversity Jurisdiction: Positive Side Effects and Potential for Further Reforms, 92 Harv. L. Rev. 963 (1979). There has also been legislative support for eliminating diversity jurisdiction. E.g., S. 2389, 95th Cong., 2d Sess., 124 Cong. Rec. 28, 30-33 (1978) (abolishing diversity jurisdiction except for alienage and statutory interpleader); H.R. 9622, 95th Cong., 2d Sess., 124 ConG. REc. 4992-5000 (1978); S. REP. No. 691, 71st Cong., 2d Sess. (1930).

3 The leading proposal for limiting and altering diversity jurisdiction is the AMERICAN Law Institute Study of the Division of Jurisdiction Between State and Federal Courts (1969) [hereinafter cited as ALI Study]. Supporting the ALI proposals are Field, Diversity of Citizenship: A Response to Judge Wright, 13 WAyne L. Rev. 489 (1967), and Wright, Restructuring Federal Jurisdiction: The American Law Institute Proposals, 26 Wash. \& Lee L. Rev. 185, 194-98 (1969). See also H. Friendly, Federal Jurisdiction 13952 (1973) (advocating substantial restrictions on diversity jurisdiction); Friendly, The Historic Basis of Diversity Jurisdiction, 41 HARv. L. REv. 483 (1928) (examining the history of the diversity grant to provide a basis for determining how far the grant should be restricted); Shapiro, Federal Diversity Jurisdiction: A Survey and a Proposal, 91 Harv. L. REv. 317, 339-55 (1977) (proposing a system of local choice). Congress has also made efforts to restrict diversity jurisdiction. A bill was introduced to enact the ALI proposal in 1971, S. 1876, 92d Cong., 1st Sess. 117 Cong. REc. 15,071 (1971), and reintroduced two years later, S. 1876, 93d Cong., 1st Sess., 119 Cong. Rec. 16,658 (1973). See also S. 2094, 95th Cong., 1st Sess., 123 Cong. Rec. 29,266 (1977) (limiting diversity jurisdiction by preventing a plaintiff from filing in the federal courts of his home state). 
and expansion. ${ }^{5}$ In the midst of this general controversy, issues stemming from the application of the present statutory grant of diversity jurisdiction, 28 U.S.C. $§ 1332,{ }^{\circ}$ remain unresolved. Article III of the Constitution permits several types of federal diversity jurisdiction. ${ }^{7}$ Section 1332 embodies the congressional grant of two

4 See, e.g., 1978 Hearings, supra note 2, at 28-44 (testimony of John P. Frank); 1 J. Moore, J. Lucas, H. Fink, D. Weckstein \& J. Wicker, Moore's Federal Practice ff 0.6[1] (2d ed. 1982) [hereinafter cited as Moone's]; Frank, Let's Keep Diversity Jurisdiction, 9 Forum 157 (1973); Frank, Federal Diversity Jurisdiction-An Opposing View, 17 S.C.L. Rzv. 677 (1965); Frank, For Maintaining Diversity Jurisdiction, 73 YALE L.J. 7 (1963); Moore \& Weckstein, supra note 1; Moore \& Wicker, Federal Jurisdiction, 1 FLA. ST. U.L. Rev. 1 (1973); Parker, The Federal Jurisdiction and Recent Attacks Upon It, 18 A.B.A. J. 433, 437-39 (1932); Parker, Dual Sovereignty and the Federal Courts, 51 Nw. U.L. REv. 407, 408-11 (1956).

Legal practitioners appear firmly opposed to limiting diversity jurisdiction. See 1978 Hearings, supra note 2, at $81,161,189,393-412$ (statements of several bar associations). According to Professor Wright, such a position on the part of the bar is rational but selfish and narrow-minded: "[Lawyers] see it from the perspective of the practitioner. They are unable to take in the overall perspective of what it does to the entire system and what it does to the entire corpus of would-be litigants." Id. at 60 .

- See, e.g., 1978 Hearings, supra note 2, at 136 (testimony of James W. Moore) (advocating a relaxed standard of review so that after a trial on the merits diversity jurisdiction could not be challenged "unless a litigant could show that he was actually prejudiced due to jurisdictional error").

- 28 U.S.C. $\$ 1332$ (1976). Section 1332 reads as follows:

(a) The district courts shall have original jurisdiction of all civil actions where the matter in controversy exceeds the sum or value of $\$ 10,000$, exclusive of interest and costs, and is between-

(1) citizens of different States;

(2) citizens of a State and citizens or subjects of a foreign state;

(3) citizens of different States and in which citizens or subjects of a foreign state are additional parties; and

(4) a foreign state, defined in section 1603(a) of this title, as plaintiff and citizens of a State or of different States.

(b) Except when express provision therefor is otherwise made in a statute of the United States, where the plaintiff who files the case originally in the Federal courts is finally adjudged to be entitled to recover less than the sum or value of $\$ 10,000$, computed without regard to any setoff or counterclaim to which the defendant may be adjudged to be entitled, and exclusive of interest and costs, the district court may deny costs to the plaintiff and, in addition, may impose costs on the plaintiff.

(c) For the purposes of this section and section 1441 of this title, a corporation shall be deemed a citizen of any State by which it has been incorporated and of the State where it has its principal place of business: Provided further, That in any direct action against the insurer of a policy or contract of liability insurance, whether incorporated or unincorporated, to which action the insured is not joined as a party-defendant, such insurer shall be deemed a citizen of the State of which the insured is a citizen, as well as of any State by which the insurer has been incorporated and of the State where it has its principal place of business.

(d) The word "States" as used in this section, includes the Territories, the District of Columbia, and the Commonwealth of Puerto Rico.

7 See U.S. ConsT. art. III, § 2, cl. 1:

The judicial Power shall extend . . . to Controversies between two or more States; - 
of these types by establishing the original jurisdiction of the federal district courts over actions between "citizens of different States"8 and between "citizens of a State and citizens or subjects of a foreign state." shall be deemed a citizen of any State by which it has been incorporated and of the State where it has its principal place of business."10 The federal courts are divided over whether section 1332(c) applies to corporations incorporated in countries other than the United States. ${ }^{11}$

At first glance, the language of section 1332(c) appears applicable to all corporations. Closer examination reveals that significant complications may arise if alien corporations are held to come within its scope. This comment will examine the consequences of applying section 1332(c) to alien corporations and will demonstrate that, without clearer authorization from Congress, that provision should not be applied to alien corporations.

\section{The Development of Diversity Jurisdiction Over Corporations}

Determining the citizenship of natural persons for purposes of diversity jurisdiction poses few problems. By contrast, Congress and the courts have struggled to define corporate citizenship since the original statutory grant of diversity jurisdiction in $1789 .{ }^{12}$ This section traces the development of the law of corporate citizenship down to its present formulation in section 1332.

\section{A. Early Notions of Corporate Citizenship}

The law of corporate citizenship originally developed through common law adjudication. Starting from the premise that a corporation exists only by virtue of the individuals who own and control it, early decisions held corporate citizenship to be derivative of the

between a State and Citizens of another State; - between Citizens of different States,

- between Citizens of the same State claiming Lands under Grants of different States, and between a State, or the Citizens thereof, and foreign States, Citizens or Subjects.

- 28 U.S.C. $\$ 1332(\mathrm{a})(1)(1976)$.

Id. $\S 1332(\mathrm{a})(2)$.

10 Id. § 1332(c).

11 See authorities cited in Moore's, supra note 4, I 0.75[3], at 709.81-.82 and $13 \mathrm{C}$. Wright, A. Mmler \& E. Cooper, Federal Practice and Procedure § 3628, at 823-29 (1975 \& Supp. 1982) [hereinafter cited as WRIGHT \& MiLLER]. Corporations incorporated in countries other than the United States will be referred to as alien corporations.

12 Judiciary Act of 1789 , ch. $20, \S 11,1$ Stat. $73,78-79$ (current version at 28 U.S.C. $\S$ 1332 (1976)). 
citizenship of its "members." a corporation shared the citizenship of all its shareholders or only of its officers and directors. ${ }^{14}$ Either definition of corporate citizenship, in light of the requirement of complete diversity, ${ }^{15}$ severely limited the ability of a corporation to gain access to federal courts through diversity jurisdiction.

In 1844, the Supreme Court restricted a corporation's citizenship to its state of incorporation. ${ }^{16}$ The Court later sought to harmonize this result with the derived-citizenship rule by explaining that, for purposes of determining a corporation's citizenship, a corporation's shareholders would be deemed to be citizens of its state of incorporation. ${ }^{12}$ The state-of-incorporation rule was extended to alien corporations in $1882 .{ }^{18}$

From 1844 to 1958, when section 1332 (c) was enacted, ${ }^{19}$ a corporation was deemed a citizen of the state of its incorporation. ${ }^{20}$ During this entire period, Congress did not exercise its prerogative to define citizenship ${ }^{21}$ for corporations except where it limited for-

${ }^{13}$ See, e.g., Bank of the United States v. Deveaux, 9 U.S. (5 Cranch) 61, 91 (1809).

14 See, e.g., Marshall v. Baltimore \& O.R.R., 57 U.S. (16 How.) 314, 328 (1853); Green, Corporations as Persons, Citizens, and Possessors of Liberty, 94 U. PA. L. REv. 202, 211-12 (1946); Comment, Limited Partnerships and Federal Diversity Jurisdiction, 45 U. CHI. L. REv. 384, 405-06 (1978).

1s See Strawbridge v. Curtiss, 7 U.S. (3 Cranch) 267 (1806) (no plaintiff may have the same citizenship as any defendant). The complete-diversity rule effectively barred a widely held corporation from suing or being sued in the federal courts. Moore \& Weckstein, Corporations and Diversity of Citizenship Jurisdiction - A Supreme Court Fiction Revisited, 77 HaRv. L. Rev. 1426, 1427-28 (1964).

${ }^{16}$ Louisville, C. \& C.R.R. v. Letson, 43 U.S. (2 How.) 497 (1844).

17 Marshall v. Baltimore \& O.R.R., 57 U.S. (16 How.) 314, 326-29 (1853); accord Saint Louis \& S.F. Ry. v. James, 161 U.S. 545, 554-55 (1896). Several commentators have noted the weakness of this patent fiction. See, e.g., MOORE's, supra note 4, I 0.75[3], at 709.80; C. Wright, Handbook of the LaW of the Federal Courts 102 (1976); Wright \& Mitler, supra note $11, \S 3623$, at 766 ; Moore \& Weckstein, supra note 15 , at 1428-30. Thus a Delaware corporation sued by a citizen of New York would satisfy the diversity requirement because the suit would be between "citizens of different States." 28 U.S.C. $\S 1332(a)(1)$ (1976).

18 National S.S. Co. v. Tugman, 106 U.S. 118, 121 (1882); see also Barrow S.S. Co. v. Kane, 170 U.S. 100, 106 (1898). See generally Moore's, supra note 4, Ti 0.75[3], at 709.80. An interesting and extensive attack on the constitutionality of this doctrine is found in McGovney, A Supreme Court Fiction (pts. 1-3), 56 HARv. L. Rev. 853, 1090, 1101-03, 1225, 1226 (1943).

10 Act of July 25,1958 , Pub. L. No. $85-554, \S 12,72$ Stat. 415 (codified as amended at 28 U.S.C. $\$ 1332$ (c) (1976)).

${ }^{20}$ Ferrigno v. Ocean Transp., Ltd., 188 F. Supp. 179, 180 (S.D.N.Y. 1960).

21 Though Congress cannot confer jurisdiction on article III courts to hear suits between aliens, see Hodgson v. Bowerbank, 9 U.S. (5 Cranch) 303 (1809); Montalet v. Murray, 8 U.S. (4 Cranch) 46 (1807); Mossman v. Higginson, 4 U.S. (4 Dall.) 12 (1800); Verlinden B.V. v. Central Bank of Nigeria, 647 F.2d 320, 325 n.17 (2d Cir. 1981), rev'd on other 
eign involvement in a few sensitive domestic industries such as shipping and minerals. ${ }^{22}$

\section{B. Enactment of Section 1332(c)}

Limiting corporate citizenship to the place of incorporation succeeded all too well in expanding corporate access to the federal courts. The usual justification for diversity jurisdiction is the fear of local prejudice against non-local parties. ${ }^{23}$ However, a corporation that operated exclusively in one state might have incorporated in another state for any number of reasons. ${ }^{24}$ For such a corporation, the usual justification for diversity jurisdiction was absent; yet it retained access to federal courts in suits by or against citizens of the state where it engaged in all of its business. Such a company, if incorporated in-state, could settle similar disputes only in the state courts. ${ }^{25}$ Similarly, a corporation could artificially create diversity by the simple expedient of reincorporation in another state. This potential for abuse of the place-of-incorporation rule was recognized in Black \& White Taxicab \& Transfer Co. $v$.

grounds, 103 S. Ct. 1962 (1983); Sadat v. Mertes, 615 F.2d 1176, 1183 (7th Cir. 1980); WRIGHT \& MinLER, supra note 11, § 3604, at 607-08 (citing cases); Mahoney, A Historical Note on Hodgson v. Bowerbank, 49 U. CHI. L. REv. 725 (1982), the Hodgson doctrine says nothing about the power of Congress to grant citizenship. If section 1332(c) is applied to an alien corporation, that corporation becomes an American citizen for diversity purposes and Hodgson no longer applies. As the American Law Institute notes, there is no substantial objection to granting citizenship to an alien corportion, if, as must be the case under the principal-place-of-business test, it has a substantial presence. See ALI STUDY, supra note 3, at 113 \& n.14. As a general matter, citizenship is not defined anywhere in the Constitution, and it has long been conceded that establishing qualifications for citizenship is a task delegated exclusively to Congress. See Chirac v. Lessee of Chirac, 15 U.S. (2 Wheat.) 259, 268 (1817) (Marshall, C.J.); see also Scott v. Sandford, 60 U.S. (19 How.) 393, 417-18 (1856).

22 In these industries, Congress required participating corporations to be United States citizens and then defined corporate citizenship for purposes of this determination within the industry. Vagts, The Corporate Alien: Definitional Questions in Federal Restraints on Foreign Enterprise, 74 HARv. L. REv. 1489, 1502-08, 1524-50 (1961). Among the methods used to define citizenship were the place of incorporation, the principal place of business, the place where those with voting control were citizens, and the place of nationality of dominant investors or management. Id.

${ }^{23}$ See infra note 89 and accompanying text.

24 For example, a corporation might incorporate in another state in order to take advantage of the more liberal corporate laws of that state. See W. Cary \& M. EISEnBErg, Cases and Materials on Corporations 9-15 (5th ed. 1982).

${ }^{25}$ The Senate report accompanying the bill which became section 1332 described this access as an "evil," noting that "[t]his circumstance can hardly be considered fair because it gives the privilege of a choice of courts to a local corporation simply because it has a charter from another State, an advantage which another local corporation that obtained its charter in the home State does not have." S. REP. No. 1830, 85th Cong., 2d Sess. 4, reprinted in 1958 U.S. Code Cong. \& AD. News 3099, 3101-02 [hereinafter cited as 1958 Senate REPORT]. 
Brown \& Yellow Taxicab \& Transfer Co., ${ }^{26}$ decided thirty years before Congress acted to solve the problem. The spur which finally brought Congress to correct this anomaly was a substantial increase in the federal court workload due largely to diversity cases. ${ }^{27}$ One of a series of measures enacted by Congress in 1958 to reduce the volume of diversity cases, ${ }^{28}$ section 1332 (c) provided for corporate citizenship in both the state of incorporation and the state where the corporation had its principal place of business. By creat-

26 276 U.S. 518 (1928). Plaintiffs, in order to get into federal courts, dissolved their corporation in Kentucky and reincorporated in Tennessee, thereby creating the necessary diversity. See id. at 523-24. Justice Brandeis took particular note of this case as an example of abuse in his opinion for the Court in Erie R.R. v. Tompkins, 304 U.S. 64, 73-74 (1938).

${ }^{27}$ The Senate report points to the increase in the "judicial business of the United States district courts," and in particular to the increase in diversity cases, as the problem that Congress wished to address. The report notes that diversity cases

have increased from 7,286 in 1941 to 20,524 in 1956. A large portion of this caseload involves corporations. Of the 20,524 diversity of citizenship cases filed in the district courts during fiscal 1956 corporations were parties in 12,732 cases, or 62 percent. This percentage is almost identical with the fiscal years 1951 and 1955.

1958 Senate RePort, supra note 25, at 2-3, reprinted in 1958 U.S. Code CoNG. \& AD. NewS at 3100. Special letters and reports printed in the Senate Report indicate that for the years 1950,1951 , and 1956, diversity cases involving a nonresident corporation doing business in the state where the suit was filed made up over $57 \%$ of all diversity cases filed in each of those years, and between 17 and $23 \%$ of total civil cases in these same years. Id. at 13-14, reprinted in 1958 U.S. CodE CONG. \& AD. NEwS at 3111 (statement of Division of Procedural Studies and Statistics, Administrative Office of the United States Courts).

These figures were prepared in response to earlier phases of the legislation, which proposed that corporations be entirely excluded from diversity jurisdiction. Therefore, they do not indicate how many of the nonresident corporations had their principal place of business in the state where the suit was filed. Nonetheless, rough estimates were made for the report of the number of cases involving corporations chartered in one state with their principal place of business in another. These figures indicated that "a small but substantial number of cases will be affected" by defining corporations to be citizens of the state in which their principal place of business is located. 1958 SENATE REPORT, supra note 25, at 14, reprinted in 1958 U.S. Code CoNG. \& AD. News at 3112. Alien corporations were never mentioned or statistically isolated.

${ }^{28}$ Act of July 25, 1958, Pub. L. No. 85-554, §§ 1-5, 72 Stat. 415, 415-16 (codified at 28 U.S.C. $\$ \S 1331,1332,1445$ (1976)). This legislation also increased the jurisdictional amount from $\$ 3,000$ to $\$ 10,000$, see 28 U.S.C. $\$ \S 1331(a)$, 1332(a) (1976), and eliminated removal jurisdiction of state workmen's compensation cases. See id. $\$ 1445(\mathrm{c})$.

The 1958 Act generated a decline of over 8,000 cases filed (from 25,709 in 1958 to 17,342 in 1959) in its first year. Administrative Ofrice of the United States Courts, Federal Judicial WorkLOAD Statistics, $80-88$ (1959) (attributing "decided drop" in civil filings principally to Act of July 25). This decrease in diversity cases has been more than offset by an increase in non-diversity cases in the ensuing years. Before 1958, diversity cases provided a majority of all federal cases. See 1958 SENATE REPORT, supra note 25, at 13, reprinted in 1958 U.S. Code Cong. \& AD. News at 3110. In 1958 diversity cases were $38 \%$ of all federal civil cases filed. Administrative Office of the United States Courts, Federal Judicial WorkLoad Statistics 80 (1959). In 1959 this figure dropped to $30 \%$, id., and by 1982 it had dropped to 24\%. Administrative Office of the United States Courts, Federal Judicial WorkLond Statistics 10 (1983). 
ing dual citizenship, section 1332(c) denies diversity jurisdiction to corporations whenever any opposing party is a citizen of either state $^{28}$ and prevents corporations from artificially creating diversity by the simple act of reincorporation in a different state.

\section{Application of Section 1332(c) to Alien Corporations}

The effect of applying section 1332 (c) to alien corporations is simply stated. If section 1332 (c) applies to alien corporations, a corporation incorporated in France with its principal place of business in New York cannot sue or be sued by a citizen of New York in the federal courts based on diversity. ${ }^{30}$ It can, however, sue or be sued in the federal courts by citizens of other states and, by virtue of its New York citizenship, can perhaps sue other aliens. ${ }^{31}$ On the other hand, if section 1332(c) does not apply to alien corporations, the common law defining the citizenship of a corporation as its state of incorporation remains in effect, ${ }^{32}$ and the hypothetical French corporation can sue or be sued in the federal courts by citizens of New York as well as of the other forty-nine states. However, it cannot then sue another alien based on diversity. ${ }^{33}$

Although commentators discussed the applicability of section 1332(c) to alien corporations soon after the provision was enacted, ${ }^{34}$ the first judicial decison to address the question was $E i$ -

${ }^{29}$ See Strawbridge v. Curtiss, 7 U.S. (3 Cranch) 267 (1806) (complete diversity between all plaintiffs and all defendants is required); supra note 15 and accompanying text.

so There is no diversity of citizenship: both are citizens of New York for purposes of section 1332.

s1 For purposes of $\S 1332$, the corporation would be a citizen of New York and there would be diversity of citizenship with other aliens. See infra notes 71-73 and accompanying text. An interesting problem would arise where an alien corporation with its principal place of business in the United States was party to a suit with another alien from the same country. Whether or not there is diversity jurisdiction in such a case is beyond the scope of this comment, but the answer would appear to be no. In cases where two domestic corporations have at least one of their two states of citizenship in common, such suits are routinely dismissed for lack of jurisdiction. See, e.g., Diesing v. Vaughn Wood Prods., Inc., 175 F. Supp. 460 (W.D. Va. 1959); Harker v. Kopp, 172 F. Supp. 180 (N.D. Ill. 1959); see also Moore \& Weckstein, supra note 15, at 1431 (any other result is inconsistent with the purposes of $\S$ 1332(c)). But see Majewski v. New York Cent. R.R., 227 F. Supp. 950 (W.D. Mich. 1964) (where corporation has multiple citizenship due to multiple incorporation, plaintiff in one state of incorporation can maintain a diversity suit); Fitzgerald v. Southern Ry., 176 F. Supp. 445 (S.D.N.Y. 1959) (same).

${ }^{32}$ See supra notes 16-18 and accompanying text.

ss See Hodgson v. Bowerbank, 9 U.S. (5 Cranch) 303 (1809) (Congress cannot give the courts jurisdiction over cases involving only aliens).

st See, e.g., Note, 72 HaRv. L. REv. 391, 394 (1958); Note, Congressional Patchwork in Federal Jurisdiction, 6 UtAH L. REv. 231, 239 (1958). 
senberg $v$. Commercial Union Assurance Co. ${ }^{35}$ In that case the United States District Court for the Southern District of New York held section 1332(c) inapplicable to alien corporations. The court began by observing that "the statute differentiates between States of the United States and foreign states by the use of a capital S for the word when applied to a State of the United States."38 The court noted further that in establishing a corporation's citizenship in its state of incorporation, the statute refers only to a corporation incorporated in a "State" of the United States, necessarily a domestic corporation. ${ }^{37}$ Since section 1332 (c) deems a corporation a citizen "of any State by which it has been incorporated and of the State where it has its principal place of business,"s8 the court concluded that the principal-place-of-business test applies only to corporations which qualified as citizens under the state-ofincorporation test, i.e., domestic corporations. ${ }^{39}$ Other courts which have followed the Eisenberg holding have repeated the capitalization argument, adding to it the observation that the legislative history does not discuss alien corporations at any point. ${ }^{40}$

The District Court for the Northern District of Illinois reached the opposite result in Southeast Guaranty Trust Co. $v$. Rodman \& Renshaw, Inc. ${ }^{41}$ That decision, and the cases which have followed it, ${ }^{42}$ disagreed with the Eisenberg court and found "no ground for concluding that because the first half of the section does not apply to foreign corporations . . . the second half should have no application to them at all."4s Moreover, these courts contend, while it may be true that Congress gave no explicit consider-

ss 189 F. Supp. 500 (S.D.N.Y. 1960).

se $I d$. at 502.

37 Id.

ss 28 U.S.C. $\$ 1332$ (c) (1976) (emphasis added).

30 189 F. Supp. at 502.

10 See, e.g., Chemical Transp. Corp. v. Metropolitan Petroleum Corp., 246 F. Supp. 563, 566-67 (S.D.N.Y. 1964). In that case the court noted that, since Congress had already used the words "State" and "state" to mean different things when it enacted $\S 1332(a)$ in 1948, this legislative silence was particularly meaningful. Id.; accord Willems v. Barclays Bank D.C.O., 263 F. Supp. 774, 775 (S.D.N.Y. 1966); Tsakonites v. Transpacific Carriers Corp., 246 F. Supp. 634, 641 (S.D.N.Y. 1965), aff'd, 368 F.2d 426 (2d Cir. 1966), cert. denied, 386 U.S. 1007 (1967).

11358 F. Supp. 1001 (N.D. IIl. 1973).

42 E.g., Jerguson v. Blue Dot Inv., Inc., 659 F.2d 31 (5th Cir. 1981), cert. denied, 456 U.S. 946 (1982); Richmond Constr. Co. v. Hilb, 482 F. Supp. 1201 (M.D. Fla. 1980); Arab Int'l Bank \& Trust Co. v. National Westminster Bank, 463 F. Supp. 1145 (S.D.N.Y. 1979).

13 Southeast Guar. Trust Co. v. Rodman \& Renshaw, Inc., 358 F. Supp. 1001, 1006-07 (N.D. Ill. 1973); accord Jerguson v. Blue Dot Inv., Inc., 659 F.2d 35 (5th Cir. 1981), cert. denied, 456 U.S. 946 (1982). 
ation to the effect of applying section 1332(c) to alien corporations, its application better serves the purpose of limiting diversity jurisdiction that moved Congress to enact the statute. ${ }^{44}$

Both positions are plausible. The bare statutory language is ambiguous, and Congress certainly has the power to deem an alien corporation a citizen of an American state. ${ }^{45}$ As courts advocating the Eisenberg position have pointed out, the legislative history does not indicate that Congress considered the application of section $1332(\mathrm{c})$ to alien corporations. ${ }^{46}$ On the other hand, as the court in Southeast Guaranty argued, applying section 1332(c) to alien corporations appears to be consistent with the overriding congressional purposes behind the statute. ${ }^{47}$ Subsequent decisions have added little to these initial positions, ${ }^{48}$ and courts remain divided, even within single districts. ${ }^{49}$

Where a question concerning the applicability of a statute arises, the starting point for analysis is the language of the statute itself. If the question remains unresolved, one must then turn to the legislative history and other indicia of congressional intent. The statutory language, legislative history, and purposes of section 1332(c) provide no certain guidance as to the section's applicability to alien corporations. Therefore, this comment will finally turn to the general policies behind diversity jurisdiction to demonstrate that section 1332 (c) should not apply to alien corporations without a much clearer statement from Congress.

${ }^{4}$ E.g., Southeast Guar., 358 F. Supp. at 1006-07; Bergen Shipping Co. v. Japan Marine Servs., Ltd., 386 F. Supp. 430, 433 (S.D.N.Y. 1974).

15 See supra note 21 .

48 See supra note 40 and accompanying text; infra notes 65-67 and accompanying text.

17 See supra note 44 and accompanying text; infra notes $69-72,85$ and accompanying text.

48 See cases cited in Moore's, supra note 4, I 0.77[2.-3]; Wright \& MilLER, supra note $11, \S 3628$ at $824-29$.

49 Compare Union Marine \& Gen. Ins. Co. v. American Export Lines, 274 F. Supp. 123, 125 n.1 (S.D.N.Y. 1966) and Mazzella v. Pan Oceanica A/S Panama, 232 F. Supp. 29, 31 n.1 (S.D.N.Y. 1964) (both holding § 1332(c) inapplicable) with Oppenheimer Reins. Co. v. Alexander \& Alexander, Inc., No. 79-2151, (S.D.N.Y. Dec. 27, 1979) and Bergen Shipping Co. v. Japan Marine Servs., Ltd., 386 F. Supp. 430, 431-34 (S.D.N.Y. 1974) (both applying § 1332(c)). 


\section{Statutory Construction}

\section{A. Plain Language}

The courts that deny the applicability of section 1332(c) to alien corporations ${ }^{50}$ begin by focusing on the capitalization of the word "State." foreign "states" is made elsewhere in the statute, ${ }^{52}$ and the term "States," as defined in section 1332(d), clearly refers only to members of the United States. ${ }^{53}$ Therefore, these courts conclude, the capitalized word "State" refers only to American states. Given this conclusion, the only real question is whether incorporation in an American state is a condition precedent to principal-place-of-business citizenship in the United States. The argument in favor of such an interpretation is quite straightforward. Section 1332(c) consists of two clauses. The first deems a corporation a citizen of "any State by which it has been incorporated," adds corporate citizenship in "the State where it has its principal place of business." Since "State" refers only to constituents of the United States, the first clause must refer to domestic corporations. If one assumes that the use of "the" and "it" in the second clause is meant to refer to corporations included in the first clause, the two clauses can be viewed as operating in conjunction with one another; section 1332(c) adds to the citizenship of domestic corporations citizenship in the "State" of their principal place of business. ${ }^{56}$ This reading makes section $1332(\mathrm{c})$ inapplicable to alien

so Capitalization, grammar and punctuation are infrequently used as aids in statutory interpretation. 2A J. Sutherdand, Statutes and Statutory Construction $\S 47.15$, at 98 (C.D. Sands 4th ed. 1973). The traditional judicial view is that "[p]unctuation is a most fallible standard by which to interpret a writing," Ewing v. Burnet, 36 U.S. (11 Pet.) 40, 53 (1837), and that "legislators are not presumed to be good grammarians." Travelers Indem. Co. v. State, 57 Misc. 2d 565, 571, 293 N.Y.S.2d 181, 187 (Ct. Cl. 1968). The most recent edition of Sutherland, however, suggests that rules of punctuation should be treated on a par with other rules of interpretation. J. SuTHERLAND, supra.

o1 See 28 U.S.C. $\S 1332(\mathrm{a})(2)$ (1976).

s2 "The word 'States,' as used in this section, includes the Territories, the District of Columbia, and the Commonwealth of Puerto Rico." Id. § 1332(d).

ss Id. \& 1332(c) (emphasis added).

Id. (emphasis added).

ss Assuming, of course, that the principal place of business is in the United States. If it is not, the corporation has citizenship for diversity purposes only in its state of incorporation, since $\S 1332$ (c) is read to refer to the principal place of business worldwide rather than just in the United States. See infra notes 61-65 and accompanying text.

so See Jerguson v. Blue Dot Inv., Inc., 659 F.2d 31, 32-35 (5th Cir. 1981), cert. denied, 456 U.S. 946 (1982); Southeast Guar. Trust Co. v. Rodman \& Renshaw, Inc., 358 F. Supp. 1001 (N.D. Ill. 1973). 
corporations; since they are explicitly excluded from the first clause, they also must be excluded from the second.

Other courts have argued that the fact that "State" refers only to one of the United States does not answer the real question: whether the two clauses of 1332(c) operate to create citizenship together or independently. ${ }^{57}$ The place-of-incorporation clause and the principal-place-of-business clause may as easily be read as operating independently. Under this reading, a corporation has suffcient presence in a "State" to be deemed a "citizen" if it is incorporated in that "State," wherever its principal place of business may be. Similarly, maintaining a principal place of business in one of the "States" constitutes a sufficient presence for citizenship in that "State," regardless of where the corporation is incorporated. To abstract this point from the language of corporations and citizenship, if a school teacher said that a child shall be considered a member of any club by which that child has been accepted and of the club where the child plays most often, frequent play would make a child a member of a club even if the child had not been accepted by any club or had joined a baseball team instead. The word "the" in reference to the principal place of business is used not to refer back to the state-of-incorporation clause, but simply because there can be only one principal place of business. ${ }^{58}$

Choosing between these two readings of the statute by relying on the language alone is difficult. As one court noted, the most one can conclude with certainty is that "the statute itself does not provide adequate guidance." 59 Moreover, reliance on such fine points of syntax to determine the applicability of section 1332(c) to alien corporations seems especially questionable in light of the many ambiguities inherent in the section's phrasing. ${ }^{60}$ For instance, the language of the section provides little help in ascertaining whether the phrase "the State where [a corporation] has its principal place of business" ${ }^{\prime 11}$ refers to a corporation's principal place of business

${ }^{57}$ See 28 U.S.C. § 1332(c) (1976) ("[A] corporation shall be deemed a citizen of any State by which it has been incorporated and of the State where it has its principal place of business . . . ." (emphasis added)).

ss Jerguson v. Blue Dot Inv., Inc., 659 F.2d 31, 35 (5th Cỉ. 1981), cert. denied, 456 U.S. 946 (1982).

so See Southeast Guar. Trust Co. v. Rodman \& Renshaw, Inc., 358 F. Supp. 1001, 1007 (N.D. Ill. 1973).

${ }^{60} 28$ U.S.C. \& 1332 (c) (1976).

61 The definition of principal place of business is an issue of no small importance, even if section 1332(c) is not applied to alien corporations, for any domestic corporation with its principal place of business outside the United States will be affected by the answer. If section 1332(c) is applied to alien corproations, this question becomes even more important: its 
in the United States, or worldwide. ${ }^{62}$ The answer appears to be the worldwide principal place of business, ${ }^{63}$ but such an interpretation can only be reached by straining the statutory language which speaks only of the "State" in which a corporation has its principal place of business.

Another obvious flaw in the drafting of section 1332(c) was pointed out by the court in Southeast Guaranty:

There are many instances in which the second half of section 1332(c) does not apply to United States corporations, i.e., where a corporation maintains its principal place of business in the same state in which it is incorporated. Since it makes no sense at all for a corporation to be twice a citizen of the same state there must be read in at the end of the section, "if the State of its principal place of business is different from the State of its incorporation. ${ }^{64}$

The observation, while overly punctilious, again demonstrates that the actual language of section $1332(\mathrm{c})$ is frequently ambiguous and

resolution will affect any alien corporation that does any business in the United States.

62 The courts have almost unanimously held that the statute refers to the principal place of business worldwide. See, e.g., Roby v. General Tire \& Rubber Co., 500 F. Supp. 480, 482 (D. Md. 1980); Arab Int'l Bank \& Trust Co. v. National Westminster Bank, Ltd., 463 F. Supp. 1145, 1147 (S.D.N.Y. 1979); Note, 22 Harv. INT'L'L.J. 688, 691 (1981). This view has been adopted both in the decisions against applying section 1332(c) to alien corporations, see, e.g., Eisenberg v. Commercial Union Assurance Co., 189 F. Supp. 500 (S.D.N.Y. 1960) (alternate holding), and in the decisions for applying the statute to alien corporations. See, e.g., Steinbock-Sinclair v. Amoco Int'l Oil Co., 401 F. Supp. 19 (N.D. Ill. 1975). The conclusion that Congress intended to use the principal place of business in the United States was implied in dictum in Sansome v. Ocean Accident \& Guar. Corp., 228 F. Supp. 554, 555 (E.D. La. 1964), but this dictum has been questioned, see Grimandi v. Beech Aircraft Corp., 512 F. Supp. 764, 773-74 (D. Kan. 1981) ("The Sansome court did not even address the issue . . . .); Arab Int'l Bank \& Trust v. National Westminster Bank, 463 F. Supp. 1145, 1147 n.2 (S.D.N.Y. 1979).

In order to reach this conclusion, the courts have argued that the logic of dual citizenship at the principal place of business is that the substantial presence of the corporation results in little possibility of bias. This logic fails where the corporation's presence in the State is miniscule, as it might be with either a domestic or alien corporation which had its worldwide principal place of business abroad. Thus, it would be against the rationale of section 1332 (c) to apply the principal-place-of-business test to the United States principalplace-of-business of an alien corporation. See, e.g., Roby, 500 F. Supp. at 482-83 (quoting Eisenberg v. Commercial Union Assurance Co., 189 F. Supp. 500, 502-03 (S.D.N.Y. 1960)).

6s 358 F. Supp. at 1007.

or The cases and commentators have been unanimous in concluding that there was an "absence of explicit Congressional consideration of the issue." Chemical Transp. Corp. v. Metropolitan Petroleum Corp., 246 F. Supp. 562, 566 (S.D.N.Y. 1965). See also Bergen Shipping Co., Ltd. v. Japan Marine Servs. Ltd., 386 F. Supp. 430, 433 (S.D.N.Y. 1974); Southeast Guar. Trust Co. v. Rodman \& Renshaw, Inc., 358 F. Supp. 1001, 1007 (N.D. IIl. 1973). 
that one must look beyond the face of the statute to determine what it means.

\section{B. Congressional Intent}

1. Legislative History. The legislative history of the 1958 Act indicates that Congress never considered the applicability of section 1332 (c) to alien corporations. ${ }^{65}$ The examples of corporate abuse of the diversity grant and the focus of the general discussion in the Senate report concern domestic corporations. After noting that the underlying purpose of diversity jurisdiction is to avoid state court and state jury prejudice against non-local parties, ${ }^{66}$ the Senate report states that diversity

was never intended to extend to local corporations which, because of a legal fiction, are considered citizens of another State. It is a matter of common knowledge that such incorporations are primarily initiated to obtain some advantage taxwise in the State of incorporation or to obtain the benefits of the more liberal provisions of the foreign State's corporation laws. Such incorporations are not intended for the prime purpose of doing business in the foreign State. ${ }^{67}$

Unlike the language of the statute, which may not be limited explicitly to American corporations, this language clearly refers to domestic corporations.

2. Statutory Purposes. The legislative history of the 1958 Act indicates that the goal of the entire Act was to "ease the workload of our Federal courts by reducing the number of cases involving corporations which come into Federal district courts on the fictional premise that a diversity of citizenship exists." 68 Thus, the statute's purposes were to reduce the federal caseload in diversity and to avoid corporate abuse of the diversity grant. ${ }^{69}$

Bs 1958 Senate Report, supra note 25, at 4, reprinted in 1958 U.S. CoDE Cong. \& AD. News at 3102.

${ }^{B B}$ Id. at 3, reprinted in 1958 U.S. Code Cong. \& AD. News at 3101.

${ }^{67}$ Id. (emphasis added).

${ }^{88}$ See supra notes 23-29 and accompanying text.

${ }^{68}$ Richmond Constr. Corp. v. Hilb, 482 F. Supp. 1201, 1203 (M.D. Fla. 1980) (Applying section 1332 (c) will eliminate "the unfair advantage given the actually local, but fictionallyforeign corporation."); Bergen Shipping Co. v. Japan Marine Servs., Ltd., 386 F. Supp. 430, 433 (S.D.N.Y. 1974) ("II]t is clear that the same rationale which precludes out-of-state but locally based corporations from invoking federal jurisdiction against locally incorporated corporations would preclude alien, but locally based corporations, from invoking such jurisdiction."); Southeast Guar. Trust Co. v. Rodman \& Renshaw, Inc., 358 F. Supp. 1001, 1007 (N.D. Ill. 1973) ("Congress sought to preclude any technical finding of diversity, when, in 
The congressional aim of avoiding abuse of diversity jurisdiction by essentially local corporations that incorporate in another state to gain access to the federal courts is equally applicable to domestic and alien corporations. Whether an essentially local corporation has incorporated in another state or in another country in order to create diversity makes little difference.

Determining the effect on the federal caseload of applying the statute to alien corporations is more difficult. In the case of domestic corporations, the only effect of section 1332 (c) is to reduce the availability of diversity jurisdiction. Applied to alien corporations, however, section 1332 (c) creates United States citizenship for diversity purposes in the state in which the alien corporation has its principal place of business, and hence may permit the alien corporation to sue another alien in the federal courts, a suit that, prior to the enactment of section 1332(c), would not have been allowed.70

That such suits may be brought is not yet established..$^{71}$ If

fact, no such diversity existed . . . . This rationale is no less compelling when applied to a corporation which has been chartered in a foreign country but maintains its principal place of business in the United States.").

70 See supra notes 32-33.

"11 Some courts have denied jurisdiction on the grounds that both parties are aliens. See, e.g., Ed \& Fred, Inc. v. Puritan Marine Ins. Undertriters Corp., 506 F.2d 757, 758 (5th Cir. 1975); Neeld v. American Hockey League, 439 F. Supp. 459, 462 (W.D.N.Y. 1977); Hercules, Inc. v. Dymamic Export Corp., 71 F.R.D. 101, 106 (S.D.N.Y. 1976). This rule, however, is inapplicable here, since section 1332(c) makes all corporations within its reach citizens of the United States for diversity purposes. A suit by an alien corporation with its principal place of business in the United States against another alien is therefore within the language of the diversity grant under section $1332(\mathrm{a})(2)$. This type of case is distinguishable from cases where there are aliens on both sides of a dispute with an American citizen as an additional party. Cf. Verlinden B.V. v. Central Bank of Nigeria, 647 F.2d 320, 325 n.17 (2d Cir. 1981) (no diversity jurisdiction under $\S 1332$, but perhaps within Congress's power under article III), rev'd on other grounds, 103 S. Ct. 1962 (1983); IIT v. Vencap, Ltd., 519 F.2d 1001, 1015 (2d Cir. 1975) (Friendly, J.) (same).

Other courts have sought to avoid this incidental increase in the availability of access to federal courts via diversity by arguing that suits between alien corporations with their principal place of business in the United States and other aliens lack complete diversity. See, e.g., Corporacion Venezolana de Fomento v. Vintero Sales, 629 F.2d 786, 790 (2d Cir. 1980), cert. denied, 449 U.S. 1080 (1981); Grimandi v. Beech Aircraft Corp., 512 F. Supp. 764, 777 (D. Kan. 1981). A judicially created doctrine deriving from Strawbridge v. Curtiss, 7 U.S. (3 Cranch) 267 (1806), complete diversity in its modern form requires that "each defendant [be] a citizen of a different state from each plaintiff." Owen Equip. \& Erection Co. v. Kroger, 437 U.S. 365, 373 (1978); see also MooRE's, supra note 4, 1 0.75[1.-2], at 709.6-.7. Such reasoning appears incorrect. The two parties are completely diverse because one has United States citizenship and the other alien citizenship and therefore diversity would be created under section 1332(a)(2), which provides for suits between "citizens of a State and citizens or subjects of a foreign state." 28 U.S.C. $\$ 1332(a)(2)$ (1976).

In support of these decisions, one can argue that insofar as the purpose of section 1332 
they cannot be brought, section 1332(c) will affect alien corporations and domestic corporations similarly, destroying diversity in the state where the principal place of business is located and, as some courts have recognized, ${ }^{72}$ furthering the congressional purpose of limiting diversity jurisdiction. Even if such suits can be brought, the number of suits between citizens of the American State which is an alien corporation's principal place of business and the alien corporation (which would be denied diversity jurisdiction) likely exceeds the number of suits brought by an alien corporation with a United States principal place of business against another alien. Thus, applying section 1332(c) to alien corporations appears consistent with Congress's purposes.

Additional support for the argument that applying section 1332(c) to alien corporations is consistent with the purposes behind the statute may be found in the history of the proviso to section $1332(\mathrm{c}) .^{73}$ In 1964, Congress added this proviso, which establishes citizenship for an insurer in the state in which the insured is a citizen, in order to eliminate diversity suits generated by state direct-action statutes. ${ }^{74}$ The few cases that have dealt with the treatment of alien insurers under the proviso have held it applicable on the ground that to do so is consistent with the purposes of the proviso as stated in its legislative history. ${ }^{75}$

is to decrease the federal caseload, the alien corporation's dual citizenship should be used to negate diversity whenever possible. Such a result achieves but a minimal reduction in the number of diversity suits, however, and comes at the expense of making section 1332 even more tortured.

72 See, e.g., Jerguson v. Blue Dot Inv., Inc., 659 F.2d 31 (5th Cir. 1981), cert. denied, 456 U.S. 946 (1982); Southeast Guar. Trust Co. v. Rodman \& Renshaw, Inc., 358 F. Supp. 1001 (N.D. Ill. 1973).

${ }^{73}$ The proviso reads:

Provided further, That in any direct action against the insurer of a policy or contract of liability insurance, whether incorporated or unincorporated, to which action the insured is not joined as a party-defendant, such insurer shall be deemed a citizen of the State of which the insured is a citizen, as well as of any State by which the insurer has been incorporated and of the State where it has its principal place of business.

28 U.S.C. \$1332(c) (1976).

7 These so-called direct action statutes had been enacted in Louisiana and Wisconsin. Under the statutes, if one party to a controversy between two citizens of the same state was insured by a non-local insurer, the other party could sue the insurer in federal court based on diversity. As a result, the federal courts in these two jurisdictions were "flooded with cases which normally would have been handled in the state courts." Torres v. Hartford Ins. Co., 588 F.2d 848, 849 (1st Cir. 1978).

${ }^{75}$ See Newsom v. Zurich Ins. Co., 397 F.2d 280, 282 (5th Cir. 1968); Narvaez v. British Am. Ins. Co., 324 F. Supp. 1324, 1325 (D.P.R. 1971). The legislative history states that the purpose of the amendment was

to eliminate under the diversity jurisdiction of the U.S. district courts, suits on certain tort claims in which both parties are local residents, but which, under a State "direct 
The same argument can be made with reference to section 1332(c) as a whole. ${ }^{76}$ However, section $1332(c)$ and its proviso are aimed at different evils. Section 1332(c) was enacted to prevent corporations from artificially creating diversity by the formality of incorporation; ${ }^{77}$ the proviso was enacted to prevent the use of direct-action statutes to evade the complete-diversity rule. The proviso thus has a narrower focus, ${ }^{78}$ a fact that vitiates the strength of any inference to be drawn from the proviso for the application of the general provisions of section $1332(\mathrm{c}){ }^{79}$ Moreover, direct-action suits against alien insurers occur very rarely, and the fact that the only two decisions regarding the proviso have both applied it to alien corporations can hardly be taken to have settled the issue. ${ }^{80}$ The most that can be said is that the two decisions lend indirect support to those federal courts that advocate applying section 1332 (c) to alien corporations. ${ }^{81}$

action" statute, may be brought directly against a foreign insurance carrier without joining the local tort-feasor as a defendant.

S. REP. No. 1308, 88th Cong., 2d Sess. 1 (1964), reprinted in 1964 U.S. Code Cong. \& AD. NEws 2778, 2778-79 [hereinafter cited as 1964 SENATE REPORT].

${ }^{28}$ The division in the courts over the application of section $1332(\mathrm{c})$ to alien corporations had not developed when the proviso was enacted. Thus, no inferences as to actual congressional intent can be drawn from the proviso or its legislative history on this issue. The legislative history of the proviso, like that of section 1332(c) itself, is silent. See supra notes 67-69 and accompanying text.

75 Supra notes 23-29 and accompanying text.

72 See 1964 Senate Report, supra note 75 , at 1-2, reprinted in 1964 U.S. Code Cong. \& AD. News at 2778-79.

70 For example, an alien insurer would have less to fear from local prejudice in a suit involving a local co-defendant insured than the typical alien corporation with a local principal place of business, since a decision adverse to the alien insurer would also be adverse to the local party.

so The two cases cited above, see supra note 75, appear to be the only ones addressing the application of the proviso to alien corporations. The decisions themselves are less than compelling. Newsom is a very brief per curiam opinion, while Narvaez is a similarly brief order which simply cites and repeats what was already said in Newsom. See Narvaez, 324 F. Supp. at 1325. Moreover, the reasoning of the decisions is less than compelling. In Newsom, for example, the court argues that "Congress placed no artificial restraint concerning foreign or alien states with a big $\mathbf{S}$ or a little $\mathbf{s}$ in its directions relating to insurers. The proviso applies to 'any direct action against an insurer . . . whether incorporated or unincorporated.'" 397 F.2d at 282 . Since Congress indeed used precisely the same big $S$ and left out precisely the same little $s$ in the insurer provision as it did in the rest of section 1332(c), it is difficult to see why the court feels that italicizing a couple of words allows it to reach a different result.

"While the proviso is possibly distinguishable from the rest of section 1332(c), see supra notes 76-78 and accompanying text, it is preferable to have the entire provision, the body of section $1332(\mathrm{c})$ as well as the proviso, operate in a consistent manner. Thus, the conclusion of the comment, that section 1332(c) should not be applied to alien corporations without a clearer statement from Congress, applies to the proviso as well. To the extent that the sparse existing caselaw and available indicia of congressional intent indicate otherwise, a 
Applying section 1332(c) to alien corporations thus appears to further the ultimate goal of Congress in enacting the statute: reduction of the diversity caseload. Yet one must be careful not to overemphasize the weight of this conclusion since the total number of cases involving alien corporations is probably small. ${ }^{82}$ More importantly, where, as here, Congress's actual intent is unknown, the coincidence of consistency with congressional purposes must be weighed against the counterintuitive and undesirable consequences which may accrue from the application of a given statutory interpretation. Section 1332(c) provides that "[f]or the purposes of this section" a corporation shall be deemed a citizen of the "State" in which it is incorporated and the "State" in which it has its principal place of business. ${ }^{83}$ If, by negative implication, section 1332 (c) is read to be exclusive, no corporation can have access to federal courts by virtue of diversity unless it is either incorporated or has its principal place of business in an American "State." Under such a reading, an entirely alien corporation could never gain access to federal courts based on diversity. This construction of section 1332(c) would repeal, sub silentio, the grant of alienage jurisdiction codified in section 1332 (a). ${ }^{85}$ Such a result could hardly have been intended. Diversity jurisdiction is designed to secure an impartial federal tribunal where fear of state court bias against non-local parties is strong. It is unlikely that, in enacting section 1332(c), Congress intended to repeal such jurisdiction for the entirely alien corporations that need its protection most ${ }^{86}$ while providing that protection for alien corporations which have a significant local presence. Furthermore, federal jurisdiction over suits between aliens and United States citizens has been in force since $1789 .{ }^{87}$ Surely Congress would not have repealed such a longstanding provision without any discussion in the legislative history. ${ }^{88}$

\footnotetext{
legislative clarification becomes all the more necessary.

${ }_{82}$ No exact statistics are available. The Administrative Office of the United States Courts, which compiles statistics of the federal judicial workload and breaks them down by significant categories, does not publish a breakdown for suits involving aliens. See, e.g., ADministrative Office of the United States Courts, Federal Judicial Workzoad StatisTICs (1983) (covering the year 1982); see also authorities cited supra note 27 (additional statistics).

${ }^{83} 28$ U.S.C. § 1332(c) (1976).

84 See supra notes 50-56 and accompanying text.

ss 28 U.S.C. $\S 1332(a)(2)-(4)$ (1976).

${ }^{88}$ See infra notes 89-96 and accompanying text.

87 Judiciary Act of 1789 , ch. $20, \S 11,1$ Stat. $73,78-79$ (current version codified at 28 U.S.C. § 1332 (1976)).

${ }^{88}$ The legislative history of section 1332 (c) is silent on the issue of its application to alien corporations. See supra notes 65-67 and accompanying text.
} 
In conclusion, the application of section 1332(c) to alien corporations would at best only minimally serve the purposes for which it was enacted, while having apparently unintended consequences for alienage jurisdiction. The next section explores the policies behind alienage jurisdiction and assesses the consequences of applying section 1332(c) to alien corporations.

\section{Policy Considerations}

1. Diversity Jurisdiction, Bias, and Alien Corporations. The basis for diversity jurisdiction is fear of local prejudice against non-local parties. ${ }^{89}$ "Alienage jurisdiction . . . is founded on more concrete concerns than the arguably unfounded fears of bias or prejudice by forums in one of the United States against litigants from another of the United States." ${ }^{90}$ The fear of bias against alien individuals in state courts applies to corporations with an alien charter as well.

According to the legislative history of section 1332 (c), one reason for the creation of dual corporate citizenship was that it was "neither fair nor proper" for a corporation to avoid trial in the courts of the state where it maintains its principal place of business "by resorting to a legal device [non-local incorporation] not available to the individual citizen." ${ }^{\text {91 }}$ Although this concern is valid

so See C. Wright, supra note 17 , at 85 . The most famous exposition of this view is probably Chief Justice Marshall's in Bank of the United States v. Deveaux, 9 U.S. (5 Cranch) 61 (1809):

However true the fact may be, that the tribunals of the states will administer justice as impartially as those of the nation, to parties of every description, it is not less true that the constitution itself either entertains apprehensions on this subject, or views with such indulgence the possible fears and apprehensions of suitors, that it has established national tribunals for the decision of controversies between aliens and a citizen, or between citizens of different states.

Id. at 87; see Guaranty Trust Co. v. York, 326 U.S. 99, 111 (1945); Erie R.R. v. Tompkins, 304 U.S. 64, 74 (1938); see also Martin v. Hunter's Lessee, 14 U.S. (1 Wheat.) 304, 347 (1816) (Story, J.). Professor David Currie has commented on the lack of empirical studies on the existence of discrimination or fear of discrimination. D. CurrIe, Federal Courts 252-53 $\&$ n.1 (3d ed. 1982). Furthermore, there are other situations in which the traditional justification for diversity jurisdiction does not explain its operation; for example, a plaintiff may sue a foreign defendant in federal court in the plaintiff's home state, even though he has no grounds to fear prejudice in a state court action. Other justifications have been advanced: for example, that the Constitution provided for diversity jurisdiction to encourage investment across state and regional boundaries. See Marbury, Why Should We Limit Federal Diversity Jurisdiction?, 46 A.B.A. J. 379, 379-81 (1960); see also Frank, supra note 1, at 2228; Friendly, supra note 3, at 495-97; Phillips \& Christenson, supra note 1, at 963-65.

so Sadat v. Mertes, 615 F.2d 1176, 1182 (7th Cir. 1980).

21 1958 Senate Report, supra note 25, at 4, reprinted in 1958 U.S. Code Cong. \& AD. News at 3102 . 
with respect to domestic corporations and American citizens, the considerations with respect to alien corporations and individuals are significantly different. An alien individual, unlike a citizen of a different state, has access to federal courts regardless of the length of his residency or the nature of his activity within the state. ${ }^{82}$ Long or indefinite residence by an alien individual is analogous to maintenance of a principal place of business by an alien corporation. Just as the principal place of business reflects the corporation's local character and the corresponding decrease in alien character, the domicile of the individual reflects the individual's attachment to the American state, with a similar decrease in alien character. In the case of the individual, however, the mere existence of an alien identification suffices to justify continued access to federal courts through diversity.

A genuinely foreign element-the foreign charter- distinguishes alien corporations from domestic corporations. For the alien corporation, as much as for the alien individual, a tie to a foreign government is an important factor justifying continued access to federal courts. ${ }^{93}$ In Eisenberg $v$. Commercial Union Assurance Co., ${ }^{94}$ the court responded to this claim with a hypothetical. If a Bahamian corporation has its principal place of business in New York, the court contended, "the inference is legitimate that it has adopted New York as its actual residence and that it is no longer entitled to be considered an outsider and to deserve the protection accorded outsiders." cause the Bahamas convey a neutral political tone to most Americans. If the corporation were chartered in a particularly controversial country, such as South Africa, Argentina, Israel, or Libya, the possibility of prejudice would be greater regardless of the "local" character of the corporation or its principal place of business. The possibility of prejudice would exist simply because of the foreign charter. A domestic corporation owned, controlled, or chartered

${ }^{82}$ See C.H. Nichols Lumber Co. v. Franson, 203 U.S. 278, 282-83 (1906); Breedlove v. Nicolet, 32 U.S. (7 Pet.) 413, 431 (1833); Sadat v. Mertes, 615 F.2d 1176, 1183 (7th Cir. 1980); Psinakis v. Psinakis, 221 F.2d 418, 422 (3d Cir. 1955).

${ }^{\text {ss }}$ Of course, an individual can only be in one place at a time while a corporation can maintain a real presence in numerous locations. This fact is irrelevant insofar as the focus is on the existence of a legitimate foreign element. The contact between the corporation and the foreign government created by virtue of foreign incorporation is the operative fact, regardless of the scope of the corporation's other activities.

of 189 F. Supp. 500 (S.D.N.Y. 1960). For a discussion of the case, see supra notes 35-39 and accompanying text.

ss 189 F. Supp. at 502. 
out-of-state need no longer fear prejudice in modern America;98 bias against at least some foreigners has not yet dissipated completely.

2. Alien Corporations and Foreign Relations. Sensitivity toward potential biases against aliens is deeply rooted in American history. Hamilton wrote in The Federalist that "the federal judiciary ought to have cognizance of all causes in which the citizens of other countries are concerned." recognized the unique nature of suits involving foreigners and the consequent necessity of providing a federal forum. ${ }^{98}$ Hamilton's concern was not so much for the individual party as for the government that recognizes that party as a citizen. ${ }^{99}$ Similarly, the American Law Institute ("ALI") concludes that "[i]t is important in the relations of this country with other nations that any possible appearance of injustice or tenable ground for resentment be avoided." 100 The ALI noted that one way of avoiding friction with foreign governments is to provide an alien with "the assurance that he can have his cases tried in a court with the best procedures the federal government can supply and with the dignity and prestige of the United States behind it."101 Other commentators have taken care to distinguish alienage jurisdiction when questioning the virtues of diversity jurisdiction. ${ }^{102}$ This sensitivity towards aliens, the product of fears of bias and fears of offending foreign governments, has been reflected in recent legislative efforts to alter or restrict diversity jurisdiction. Alienage jurisdiction has consistently been distinguished and retained. ${ }^{103}$

96 Broussard v. Columbia Gulf Transmission Co., 398 F.2d 885, 889 n.5 (5th Cir. 1968) ("[T]he anachronistic belief that federal jurisdiction will treat out-of-state individuals or corporations more fairly than state processes simply does not hold validity in an era when rapid transportation and communication have made us citizens of a nation rather than subjects of local bigotry.").

97 The Federalist No. 80, at 517 (A. Hamilton) (E.M. Earle ed. 1941).

ss See, e.g., Martin v. Hunter's Lessee, 14 U.S. (1 Wheat.) 304, 335 (1816) (Story, J.).

29 The Federalist, supra note 97, at 516-18.

100 ALI STUdY, supra note 3 , at 108.

201 Id. The general ALI argument for the retention of diversity has special force in alienage cases:

Ever since 1789 the federal government has pledged to travelers away from their home states the even-handed justice of its own courts. This pledge is so woven into the fabric of our society that it is taken for granted. It should not lightly be withdrawn. General diversity jurisdiction should be retained unless it can be asserted with confidence that the shortcomings of state court justice which originally gave rise to it no longer exist to any significant degree.

Id. at 106; see also C. WRight, supra note 17, at 93.

102 See, e.g., H. Friendly, supra note 3, at 149-50; Currie, supra note 2, at 8.

${ }^{103}$ See, e.g., 1978 Hearings, supra note 2, at 27 (testimony of Rep. Kastenmeier) (ex- 
Foreign governments have an economic and sometimes a political stake in the fortunes of corporations chartered in their countries. The possibility that in some instances neither bias nor fear of offending a foreign government may exist does not mean that all or even most corporations with alien charters should be restricted in their access to federal courts. Determining the likelihood of bias or of offending a foreign government as well as the potential effects on foreign trade and commerce is a task appropriate for Congress and beyond the competence of a court. ${ }^{104}$ Unfortunately, Congress did not consider these factors when it enacted section 1332(c). ${ }^{105}$ The importance of these matters, when combined with the inability of courts to assess them, supports the exclusion of alien corporations from section 1332(c) without a clearer statement from Congress of a contrary intention.

3. Applying the Principal-Place-of-Business Test. The principal-place-of-business test has been difficult to apply to American corporations, ${ }^{106}$ especially to large, diffuse corporations conducting business in many states. ${ }^{107}$ This determination can only become more difficult, and hence more likely to produce controversial results, if applied to alien corporations. Intricate corporate arrangements and doctrines such as piercing the corporate veil only add to the difficulty. ${ }^{108}$ The legislative history of section 1332 (c) indicates that Congress thought the principal-place-of-business test had "ample precedent" in the provisions of the Bankruptcy Act and

plaining that H.R. 9622, a proposed bill to abolish diversity jurisdiction, would preserve it "in the case of the true alien, the foreign citizen or foreign national or foreign state").

${ }^{104}$ In Chemical Transp. Corp. v. Metropolitan Petroleum Corp., 246 F. Supp. 563 (S.D.N.Y. 1964), the court responded to the argument that applying section 1332(c) to alien corporations is consistent with the overriding congressional purposes for the statute by explaining that

if $\S 1332$ (c) is to apply to alien corporations, it is for Congress and not this Court to so provide. In making such a determination, Congress may not consider the policy reasons supporting the enactment of $\S 1332$ (c) controlling. Congress, for example, might wish to determine . . . whether applicability of $\S 1332$ (c) to alien corporations would have a negative effect on foreign trade or commerce....

Id. at 567 (citation omitted); see also Salomon Englander Y Cia Ltda. v. Israel Discount Bank, Ltd., 494 F. Supp. 914, 918 (S.D.N.Y. 1980) ("[U]nique policy considerations relevant to foreign corporations may come into play which Congress is best suited to address.").

${ }^{103}$ See supra notes 65-67 and accompanying text.

${ }^{106}$ See D. CuRRIE, supra note 89, at 332-34; C. WrIGHT, supra note 17, § 27, at 103-05; Currie, supra note 2 , at $36-39$.

${ }^{107}$ In such cases the factual determination of which state is the principal place of business can become extremely complex. 1958 SENATE REPORT, supra note 25, at 4, reprinted in 1958 U.S. CoDE CoNG. \& AD. NEws at 3102 (discussing how § 1332(c) will work differently as applied to corporations which do business over a large number of states).

${ }^{108}$ See, e.g., Grimandi v. Beech Aircraft Corp., 512 F. Supp. 764, 769 (D. Kan. 1981). 
cases construing them. ${ }^{109}$ Yet the principal-place-of-business test of the Bankruptcy Act applied only to domestic corporations, ${ }^{110}$ and Congress gave no guidance as to whether or how the principal place of business of alien corporations should be determined. Given the special concerns that arise in cases involving alien corporations, the decision to extend the principal-place-of-business determination required by section 1332 (c) to suits involving alien corporations ought only to be embarked upon after a weighing of policy, for which Congress and not the courts is best suited.

Congress has adopted statutes conferring jurisdiction on federal courts for suits involving corporations connected with particular industries, such as shipping, ${ }^{111}$ where foreign incorporation presented a problem. ${ }^{112}$ If Congress decides that a selective, industry-oriented approach is insufficient to prevent abuse of alien incorporation, it can easily enact rules for evaluating the extent to which an alien charter truly reflects alien interests. On the other hand, Congress could choose to apply section 1332(c) to alien corporations. The question is not whether Congress could or should so choose but whether it has already chosen. The fact that Congress has enacted statutes providing jurisdiction for alien corporations in specific industries, when combined with the seeming undesirability of the method provided for doing so in section $1332(\mathrm{c})$, militates against so concluding.

In enacting section 1332 (c), Congress sought to deny diversity jurisdiction in situations in which a corporation's local presence made the diversity grant unnecessary. ${ }^{113}$ Where alien corporations

1091958 Senate Report, supra note 25, at 5, reprinted in 1958 U.S. CoDe Cong. \& AD. News at 3102 . Cases construing the test are listed in the appendix to Kelly v. United States Steel Corp., 284 F.2d 850, 855 (3d Cir. 1960). Professor Moore commented that "[a]mple precedent there was, but consistent precedent there was not." Moore \& Weckstein, supra note 15 , at 1439 .

110 Bankruptcy Act of 1898, 11 U.S.C. $\S 11(a)(1), 30$ Stat. 544, 545, § 2 (repealed 1978) (distinguishing bankrupts "who have had their principal place of business . . . within their respective territorial jurisdictions" from bankrupts "who do not have their principal place of business, reside, or have their domicile within the United States, but have property within their jurisdictions or who have been adjudged bankrupts by courts of competent jurisdiction without the United States, and have property within their jurisdictions . . . .").

121 Merchant Marine (Jones) Act of 1920, ch. 250, 41 Stat. 988 (codified as amended in scattered sections of 46 U.S.C.). The same sorts of potential abuses exist in Jones Act cases as in diversity cases: a shipowner may seek foreign registration to avoid American law. The courts have avoided such abuses by "disregarding paper maché formalities of nominal foreign registration" on a case-by-case basis as the need arises. Tsakonites v. Transpacific Carriers Corp., 246 F. Supp. 634, 637 (S.D.N.Y. 1965); see also Bartholomew v. Universe Tankships, Inc., 263 F.2d 437 (2d Cir.), cert. denied, 359 U.S. 1000 (1959).

${ }^{212}$ See supra note 22 and accompanying text.

113 See 1958 SENATE REPORT, supra note 25, at 3-4, reprinted in 1958 U.S. Code Cong. \& AD. News at 3101-02. 
are involved, the principal-place-of-business test does not take into account the alien character of a corporation. Indeed, it entirely fails to address the issue.

\section{Conclusion}

Congress's actual intent with respect to the application of section 1332(c) to alien corporations remains unclear. The language of the provision can be read to support its application to alien corporations, and applying the provision is consistent with Congress's overriding purposes. At the same time, there are strong arguments against applying section 1332 (c) to alien corporations. The language of the provision is far from clear, and a reading that bars the application of the provision to alien corporations is certainly defensible. Moreover, a literal reading of section 1332 (c) produces results unlikely to have been intended by Congress. It is fairly clear that Congress did not even consider the matter, and there are numerous and weighty policy considerations suggesting that if Congress had considered it, Congress might well have excluded alien corporations from the ambit of section 1332 (c).

The decision whether section 1332(c) does or does not apply to alien corporations is one to be made by Congress and not the courts. The continuing division of the federal courts on this issue suggests the need for a legislative solution. In the absence of a clear legislative statement, section 1332(c) should not be applied to alien corporations. 